\title{
ANDROID BASED BINUS PROFILE APPLICATIONS AS THE MARKETING TOOLS OF BINA NUSANTARA UNIVERSITY
}

\author{
Karto Iskandar \\ Computer Sciences, Computer Sciences Department, Bina Nusantara University, Jakarta, Indonesia
}

\begin{abstract}
Smart phones with apps in it is not a new phenomenon. Both of technologies have been fused with the lifestyle today. The ease and speed of access to information makes a lot of companies use it in the process of marketing a product to the public. Objective of this action is to win the competition that more competitive. The purpose of this research is to create mobile application android based to assist in the marketing and introduction Bina Nusantara University profile to prospective students. This research method using software engineering waterfall model to produce Android-based mobile applications. The results in the form of Androidbased mobile application that can be used as a viral marketing tool for Bina Nusantara University. At the end of this study can be generated that mobile technology can be used as a media for effective marketing and branding, especially for Bina Nusantara University. Android technology based for marketing applications suited to the Bina Nusantara University applicant segment which are generally young people. The future along with the improvement of network quality and affordable cost, then the application can be made online, so features such as chat, maps, and other can be used optimally.
\end{abstract}

\section{Introduction}

This research is a continuation of a previous study, entitled "Android based mobile application design as a medium of marketing at Bina Nusantara University". In the previous research says Bina Nusantara University (BINUS University) will conduct marketing strategies using android based mobile applications. Because it is right on target and the strategy is also considered quite economical to reduce the cost of marketing.

Marketing is the process of introducing the product to the public. In fact the process of marketing spend huge cost, so BINUS University do other strategies using android technology based mobile applications. It is quite effective and appropriate for the introduction of BINUS University to its target segment, the high school and the young people.

Problems to meet the needs of people, especially high school students to know the profile of BINUS University, then made an application BINUS profile that can be used on mobile devices based on Android. Features contained in this application is that users can know the profile of BINUS University, know the programs offered, knowing the existing campus facilities, to know and be able to see the location of the campus, and find out the latest news and events from BINUS University. In this application also has a feature to connect to social networking such as facebook and twitter.
Research proposal is to continue the previous research of the design into a mobile application based on android BINUS profile to support the process of marketing a useful introduction to the public, especially high school students about institutions BINUS University.

Objectives to be achieved in this research is to produce an Android based mobile applications are listed in the Android Market / Google Play to support the marketing and introduction to the public, especially high school students to institutions of BINUS University. This application can also be accessed by those outside Indonesia, to increase the number of foreign students studying at BINUS University. With this application they can know BINUS without having to come to campus. This is in line with the vision and mission of the BINUS University who want to be a world class university.

\section{Methodology}

The research will be conducted using Waterfall Methodology, can be seen in Figure 1. Design methodology System Development Life Cycle (SDLC) is used in this paper is a Waterfall Process Model. Waterfall model is a sequential software development process, in which progress is seen as flowing steadily downwards (like a waterfall) through the phases of conception, Initiation, Analysis, Design, Construction, Testing and Maintenance [8]. 


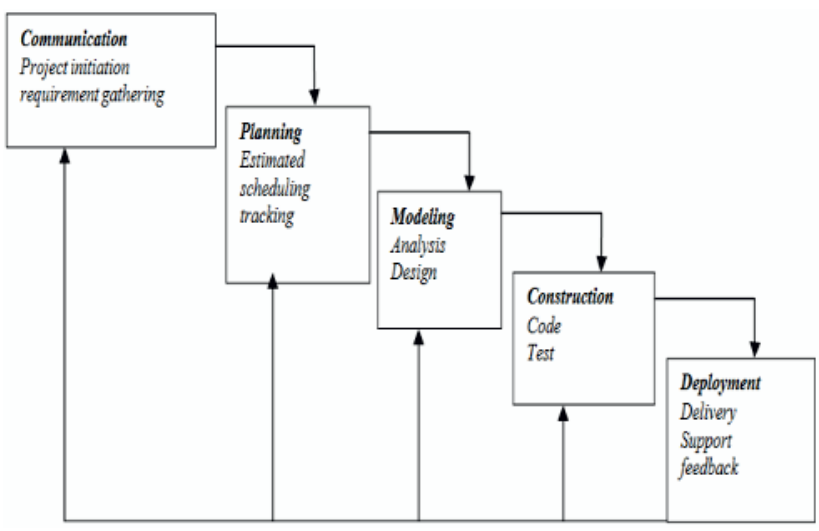

Figure 1: Waterfall Model

\section{A. Higher Education Business Processes}

Business processes in a university standard in Indonesia, which draws on data reporting of Higher Education / EPSBED can be illustrated in Figure 2 [5]. In the main process, beginning with the Admission process in which a new admissions process. Inside here there is certainly a useful marketing process to introduce the institution to the community. Marketing is the process of introducing the institution there are stages, then make users want to know, and then make the user interested, and finally make users register on BINUS.

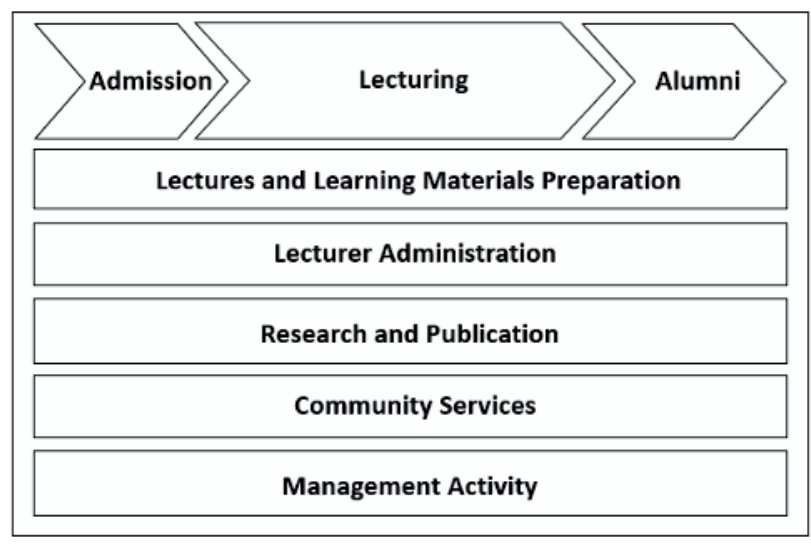

Figure 2. Higher Education Business Processes

\section{B. Marketing}

Marketing is a social and managerial process by which individuals and groups obtain what they need and want by creating and exchanging products and value with others [7].

Marketing is a process in satisfying the needs and desires of humans. So any activity in relation to the satisfaction of human needs and desires are part of the marketing concept. Marketing begins with the fulfillment of human needs which later grew into the human desire. Process in the fulfillment of human needs and desires that is the concept of marketing. Ranging from product fulfillment, pricing, shipping, and promotional items. A person who works in marketing called marketers. The marketer should have knowledge in the concepts and principles of marketing so that marketing activities can be achieved in accordance with the needs and desires of humans, especially the intended consumer [2].

Marketing concept is marketing management philosophy which states that the key to achieving organizational goals depends on determining the needs and wants of the target market and the desire of giving satisfaction more effectively and efficiently than other competitors. There is not an important factor in the marketing concept, namely: customer orientation, coordination and integration within the company, and Gaining profit through customer satisfaction [7].

Marketing strategy is the marketing logic by which the business unit hopes to achieve its marketing goals, to achieve that the marketing manager must make fundamental decisions on expenditures, marketing mix and allocation [7].

\section{Mobile apps as a marketing tools}

Why mobile gadget can support mobile activities? Such as marketing information, here are a few main reasons: 1. Cellular Gadget allows consumers to connect with each other anytime and anywhere, so it is suitable to be used as viral marketing media. The grounds are kept connected to the network, then the user is also able to receive and send SMS and MMS between users. Also users can also access the internet with WAP or GPRS technology. 2. PDAs (personal digital assistants), digital gadget is a small tool which allows to run multimedia files. PDA also have Operation System, which makes the gadget can perform these tasks should be done by computer. 3. Gadget's like a small computer that is lightweight and can carry it everywhere with computer functions. 4. With $3 \mathrm{G}$ enabled generation network capabilities with the ability to transfer data is much faster and better, with an average of 4 times faster than the previous network models, then the network can be concluded at this time is not a problem in the use of media as a media gadget that will we use, one of them in the media marketing [4].

Here are some technologies that can be used in mobile applications: 1. GSM, 2. GPRS, 3. WAP, 4. Bluetooth, 5. SMS, 6. MMS. Of all the technologies available internet network is a technology that will be used in applications with the ability to push information.

\section{Use-Case Diagram}

Use case diagrams represent the sequence of actions involved in the system, and the actors representing people or other systems that interact with the system being modeled. Use case diagram supported by specific behaviors, which define interactions in a use case section. Actor and use case is the second major element in the description. Actors and use cases can be connected to each other, and can complement each other in a structure the use case diagram [3].

\section{E. Android}


Android is a software platform for mobile devices powered by Google's OS, initially developed by Google and later the Open Handset Alliance. It allows developers to write managed code in the Java language, controlling the device via Google developed Java libraries. Applications written in $\mathrm{C}$ and other languages can be compiled to ARM native code and run, but the construction of this road is not officially supported by Google. Android is an open operating system that is intended for mobile devices (Mobile device). Developed by the Open Handset Alliance, which consists of software developers, hardware providers, such as Google, HTC, Intel, Motorola, Qualcomm, T-Mobile, and NVIDIA which aims to create an open standard for mobile devices (mobile device). In android application development Android SDK provides the tools and APIs to provide application developers with android platform. Android uses Java as the programming language [1].

\section{Result and Discussion}

Profile BINUS application for android based BINUS University made based on the needs and Marketing Process. Where the needs of the Marketing Process, the main objective is how to introduce the existence of BINUS University to the wider community. And enhanced curiosity towards BINUS University. The level of curiosity is the beginning stages of awareness later increased to interest, desire and continued to be followed by the final action. Action here can be attended open house or to purchase form. Explanation of these stages can be seen in Figure 3. The mobile application has a target market in the first two stages, namely stages of awareness and interest.

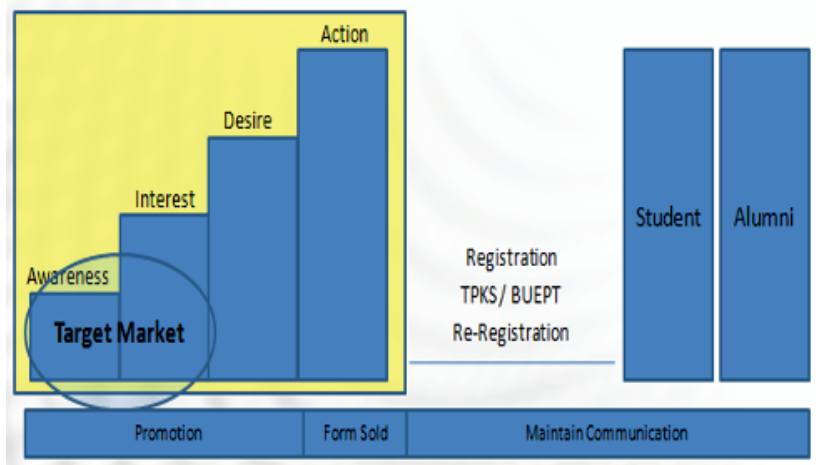

Figure 3. Stages of the prospective student's curiosity level

\section{A. Use Case BINUS Profile}

On the use case diagram for mobile applications BINUS Profile This prospective students can perform several actions related to the process of marketing. The initial stage is the admin to upload / update the application, if there is the latest application updates. Then the user can do View Home, Welcome page, View Program, Campus View and other online features are incorporated in the "More" menu. Use Case Profile BINUS application can be seen in Figure 4.
Program on View module, users can also see the Program Details. This module is the main module of the application, where users can see all the programs that exist at BINUS University and along with detailed information on the program. Module View Campus is also become an important module in this application given segment BINUS University mostly from outside the area or even overseas. On the Campus Module View can also make phone calls to the University, send email, and can see a map of the location of BINUS University.

More module is a module which requires an internet connection. In which there are several modules such as: accessing Site BINUS, Admission access site, see scholarship information, access the library site, see RSS News, Career BINUS access site, access the Alumni site, access social media sites at Facebook and Twitter BINUS. All of these modules require an internet connection or data packets.

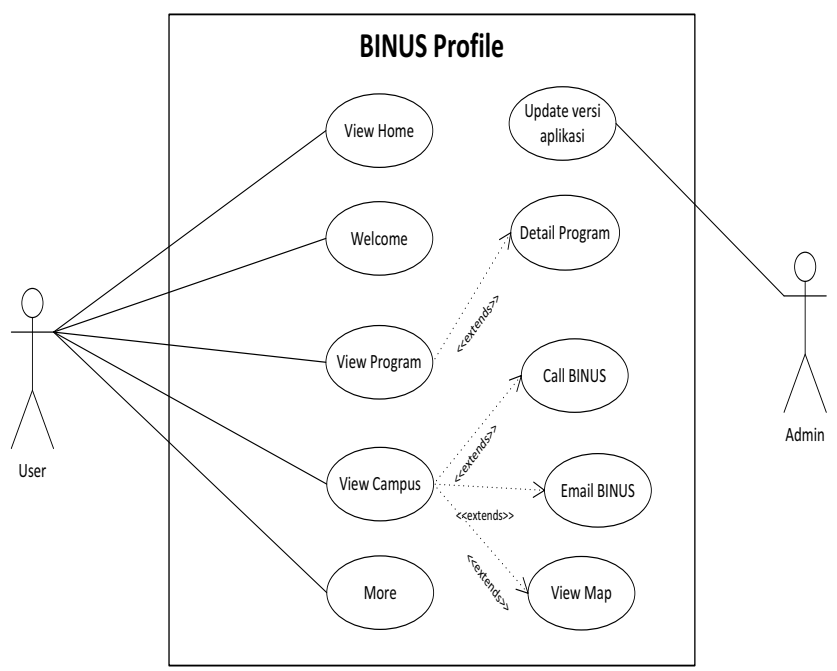

Figure 4. Use Case Diagram BINUS Application Profile

\section{B. User Interface}

Display Home screen is the main screen that users see after opening the application. On this screen there is a logo on the screen BINUS University. This logo is important because as the identity of the institution. In the middle of the screen there is a photo recognition that alternated University. And at the bottom there is a menu application. Home screen image can be seen in Figure 5.

Welcome screen display is the second menu option, where users can see the vision and mission, said welcome from Rector, and see the history of BINUS University. Thirdly it is important to remember the segment you want to reach is outside the location. On the screen above the screen there are also BINUS University logo. In the middle of the screen there are three features. To exchange one of three of these features can be done by sliding (slide) the screen. And bottom of the screen there is also a menu of applications. On this menu as a navigation menu to toggle. Navigation is made easy and simple deliberately given segment of users are students who just graduated high school / high school. Display welcome screen has a resemblance to the Home screen display, it is made as based on the theory Schneiderman [9] in the 
eight golden rules, points to one and to two, namely the consistency and ease of a universal user.

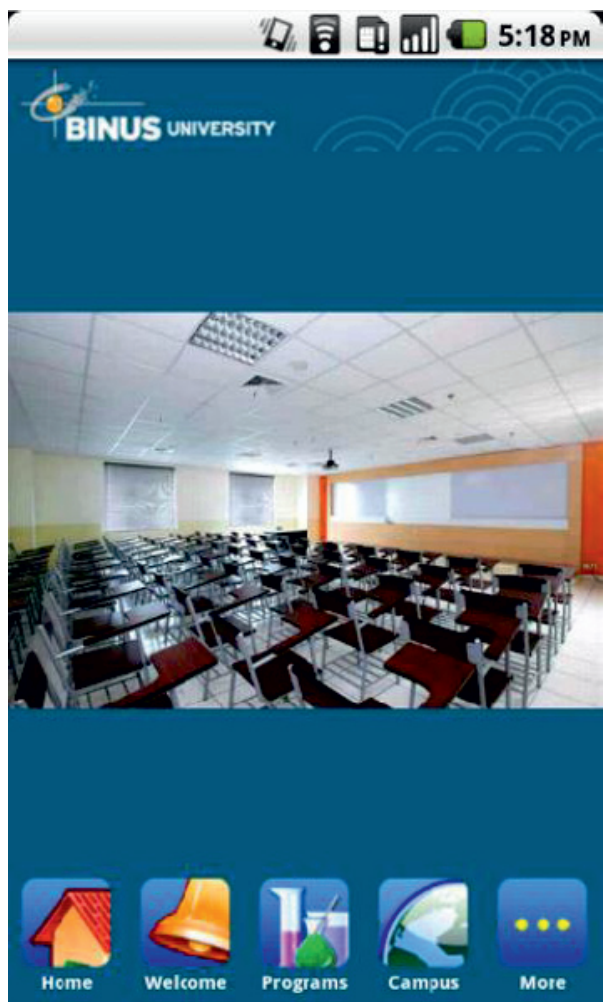

Figure 5. Home Module Screenshots

Program Menu screen display screen is a third option, where users can see all the programs that exist at BINUS University. On the menu is also pertinent to Menu Detail Program, where after seeing the program, the user can see from the details of the desired program. Program module is the main module of the mobile application. Program information can be obtained from the user's application program is similar to the information that can be obtained from the printed brochure. With this module, allows for the dissemination of information more quickly and efficiently.

For BINUS University has several advantages, such as the occurrence of viral marketing, cost savings, and a broader scope branding. For the user as if they have an electronic brochure. They can bring that information easily anywhere, and can access anytime they need. For example, when they are in class, or are get-togethers with their friends, and were talking about universities that want to target after graduating high school / high school, then they can view the information from the program and the application program is Module View. Advantages for the world is reduced paper usage, thus supporting the preservation of nature (Go Green), I hope this little contribution can maintain the sustainability of our planet. The program menu screen display can be seen in Figure 6.

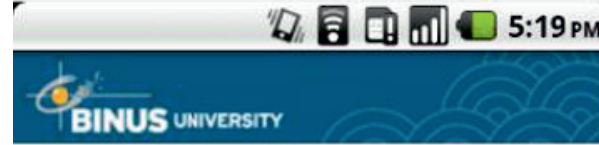

Accounting and Information Systems

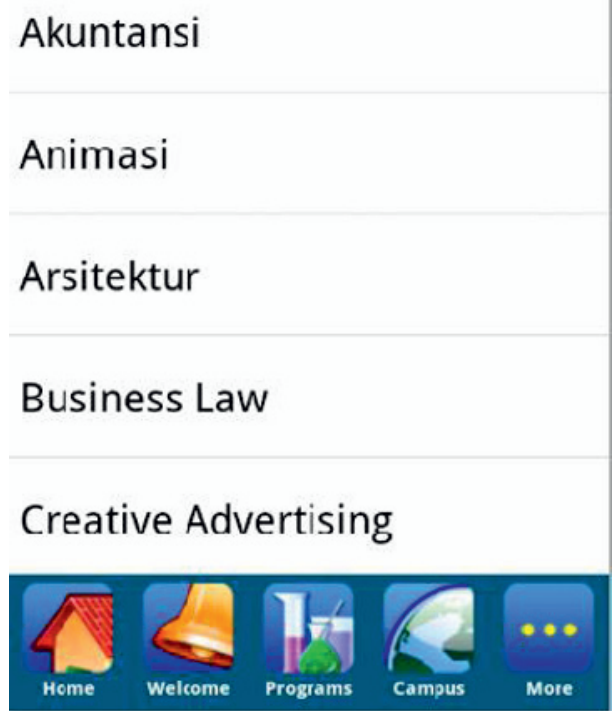

Figure 6. Program Module Screenshots

View Program Details Module is a continuation of the program. On-screen display module looks simple by maintaining the University logo and information program selected. At the bottom, there is a back button to return to the Module View Program. Program Detail View screen can be seen in Figure 7.

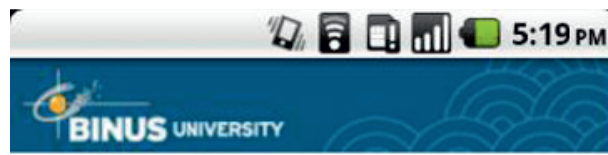

Accounting and Information Systems (S1)

Melalui program Accounting and Information Systems, kamu akan memperoleh keahlian di bidang akuntansi dan pemahaman di bidang sistem informasi, sehingga kamu akan menjadi akuntan profesional yang mampu menghasilkan sistem akuntansi berbasis teknologi informasi.

Karir setelah lulus kuliah:

Melalui program Accounting and Information Systems, kamu akan memperoleh keahlian di bidang akuntansi dan pemahaman di bidang sistem informasi, sehingga kamu akan menjadi akuntan profesional yang mampu menghasilkan sistem akuntansi berbasis teknologi informasi.

Figure 7. Program Details Module Screenshots 
The display screen is an option Campus fourth screen, where the user can see all the existing campus at BINUS University. The campus module is important because given segment of BINUS University majority are graduates of high school / high school outside Jakarta. So that information such as what BINUS University campus became important as a basic information they consideration in determining who will be selected universities. On the display to see the campus, while maintaining the previous design, which is the location of university logo remain on the top of the screen and the bottom of the screen there is a navigation menu. Information you want displayed on this module are in the middle of the screen. In the middle of the screen there is a tab BINUS University campus. Until now BINUS University has five campuses, namely: Syahdan Campus, Anggrek Campus, Kijang Campus, JWC Campus and Alam Sutera Campus. The fifth campus located disparate and have different buildings. In each of the buildings tab there is a picture of each building. In this module the user can see a picture of the exterior looks. The user can see the building moved from one building to another by selecting the tab you want to view the building. The display screen is made simple and easy to use in accordance refer of eight golden rules of law Schneiderman [9]. Campus-screen display can be seen in Figure 8 .

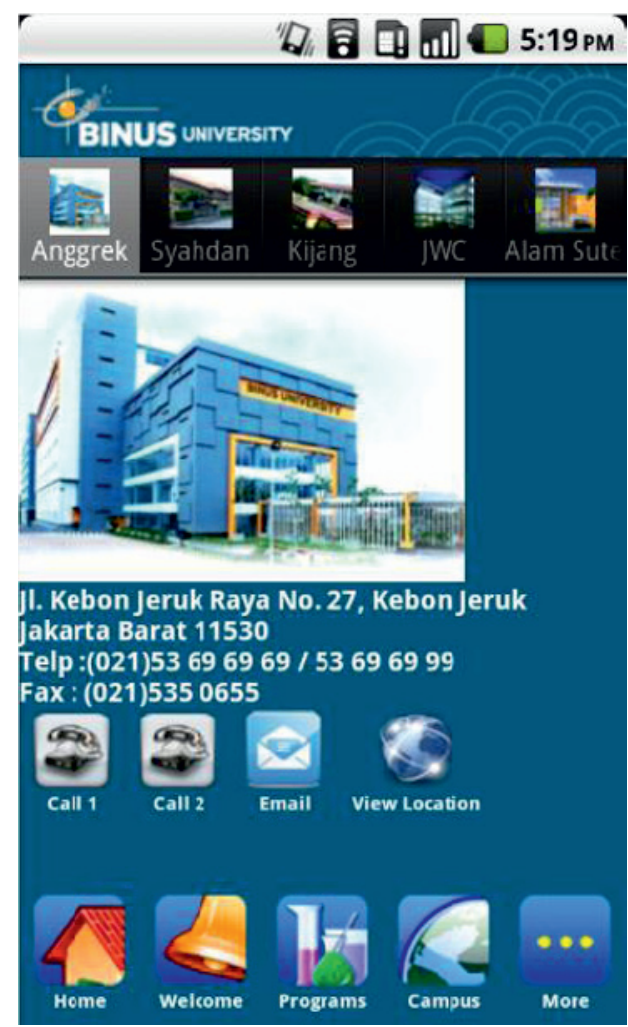

Figure 8. Campus Module Screenshots

On each tab in the Campus module, there are pictures of buildings were selected. Then under the picture of the stretcher contained useful information that morning user. Such information is address information, if the user wants to visit BINUS University someday. Then users can also make a phone call to the selected campus. Each campus has a different phone number. Then users can also send an email to the campus and communicate via this email. The email feature is important in this era, because today almost all high school students / high school and has had email communication via email is a form of communication which is effective and efficient. In this module the user can also view the location of the campus in the android map feature. Looking at this map useful for users who want to visit BINUS University. The information is as if instead of an electronic business card that can be carried by the students so that they can be useful at times of need relevant information at BINUS University campus.

Last screen appearance in this application module is a module "More". More on Modules require users will need an internet connection to access the sub modules contained in this module. "More" screen display can be seen in Figure 9.

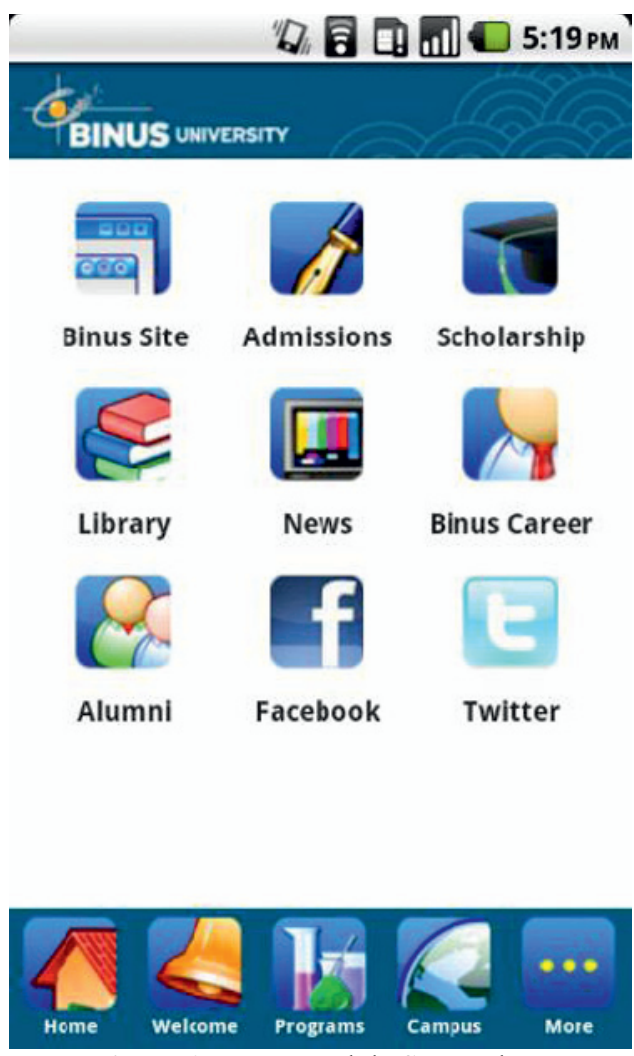

Figure 9. More Module Screenshots

More in the module, there are several modules such as: accessing Site BINUS, Admission access the site, see scholarship information, access the library site, see RSS News, Career BINUS access site, access the Alumni site, access social media sites at Facebook and Twitter BINUS. On Site BINUS sub modules access, users can see the website of the University with ease, without the need to remember the website URL address BINUS University. Similarly, the Admission site. Site Admission is a useful site for students to interact with university students in the recruitment process. Scholarship on sub modules, there is useful information related to the existing scholarship on BINUS University. In this module is important information for prospective students, as BINUS University offers many scholarship programs that 
appeal to prospective students. No less important sub modules that connects users on social media is a trend today, namely Facebook and Twitter. This is related to the desired segments, namely youth, high school / high school and the wider community.

All of the modules contained in this Profile BINUS application, made by the basic needs of prospective students in choosing a college as as their continued learning. This mobile application gives much needed information such as program information, campus information, location, mission and vision of the University. With this application, will increase the number of students who will enter to BINUS University.

\section{Implementation and Application}

Android based mobile application BINUS Profile has been developed and has been implemented by uploading them on Google Play / Android Market by searching for keywords BINUS Profile. With this application implemented on the Google Play / Android Market then all android smart phone users can use this application.

\section{Applications Testing Results}

After uploading on Google Play / Android Market, then testing the installation on multiple versions of android based smart phone. Testing was also done to try all the features of the application BINUS this Profile. The test results concluded that the application BINUS Profile is feasible to implement and is compatible with all versions of android that circulate in society today. The test results are shown in Table 1.

Table 1. Applications Test Results Table.

\begin{tabular}{|c|c|c|c|}
\hline \multirow{2}{*}{$\begin{array}{l}\text { Android } \\
\text { version }\end{array}$} & \multicolumn{3}{|c|}{ Examination } \\
\hline & $\begin{array}{c}\text { Installation } \\
\text { from .apk file }\end{array}$ & $\begin{array}{c}\text { Installation from } \\
\text { Google Play }\end{array}$ & $\begin{array}{l}\text { All features } \\
\text { work well }\end{array}$ \\
\hline $\begin{array}{l}\text { Cupcake } \\
\text { Donut } \\
\text { Eclair }\end{array}$ & \multicolumn{3}{|c|}{$\begin{array}{l}\text { Testing can not be done, because it was not found in } \\
\text { the market. }\end{array}$} \\
\hline Froyo & OK & $\mathrm{OK}$ & $\mathrm{OK}$ \\
\hline Ginger Bread & $\mathrm{OK}$ & $\mathrm{OK}$ & $\mathrm{OK}$ \\
\hline Honey Comb & OK & $\mathrm{OK}$ & $\mathrm{OK}$ \\
\hline $\begin{array}{l}\text { Ice Cream } \\
\text { Sandwich } 4.0\end{array}$ & $\mathrm{OK}$ & $\mathrm{OK}$ & $\mathrm{OK}$ \\
\hline Jelly Bean 4.1 & $\mathrm{OK}$ & $\begin{array}{l}\text { The first error, then } \\
\text { OK }\end{array}$ & $\mathrm{OK}$ \\
\hline Jelly Bean 4.2 & $\mathrm{OK}$ & $\begin{array}{c}\text { The first error, then } \\
\text { OK }\end{array}$ & $\mathrm{OK}$ \\
\hline
\end{tabular}

\section{Conclusion}

Based on these results, it can be concluded that mobile technology today can be used as a tools for marketing and branding is effective on the stage of Awareness and Interest. Applications BINUS Profile with android match segment BINUS University which are generally young age range. Mobile applications can be used as the medium of e-brochures are effective and efficient because it will always be taken anywhere and everywhere, so it can be accessed anytime and anywhere at low cost.

\section{References}

1. Anonym, "Android (Operating System)," internet Wikipedia

http://id.wikipedia.org/wiki/Android_sistem_operasi, (30 January 2012).

2. Anonym, "Marketing," internet Wikipedia http://id.wikipedia.org/wiki/Pemasaran, (30 January 2012).

3. Bennett, S., Skelton, J., and Lunn, S, Schaum's Outlines UML, 2nd ed., McGraw-Hill: Washington, D.C, (2005), pp.20-25.

4. Hamzah, Mahizer, "Mobile Learning: New Era in Malaysia," Jurnal Pendidikan Dasar. Universitas Negeri Surabaya, vol. 10, pp. 153-156. 2009.

5. Iskandar, Karto. "Perancangan Sistem Informasi Akademis Perguruan Tinggi dengan Menggunakan Diagram Use Case dan Rich,”. ComTech Vol 3. ISSN: 2087-1244. Universitas Bina Nusantara. Jakarta. (2012). pp. 654-662.

6. Iskandar, Karto, "Perancangan aplikasi mobile berbasis android sebagai media marketing pada Universitas Bina Nusantara," in press.

7. Kotler, Armstrong. Marketing an Introduction, Ninth Edition. New Jersey: Prectice Hall, (2009). pp. 1660.

8. Pressman, R. S. Software Engineering a Practitioner's Approach. (6th edition). New York: McGraw-Hill. (2006). p.79.

9. Schneiderman, B., \& Catherine P. Designing The User Interface: Strategies for Effective HumanComputer Interaction. (4th edition). Boston: Addison Wesley. (2006). p.80. 